\title{
Efek Air Perasan Umbi Bawang Merah (Allium ascalonicum L.) terhadap Profil Lipid Plasma Mencit (Mus musculus)
}

\author{
Ismawati ${ }^{1}$, Sri Wahyuni ${ }^{2}$, Nora Wirna ${ }^{3}$
}

\begin{abstract}
One of atherosclerosis risk factor is dislipidemia. One of plant that is expected to overcome dislipidemia is shallot (Allium ascalonicum L.). The aim of this research was to know the effect of shallot's extraction water on the plasma lipid profile of mice. Groups with treatment consist of yolks group, and shallot water extraction divided into three treatmen level ; 20\%, 40\% and 80\%. Parameters that were measured were total cholesterol level, LDL, HDL and plasma triglyceride of mice in the end of treatment. Simvastatin and aquadest were separately used as positive and negative control. This research proves that shallot's extortion water has effect in decreasing the level of total cholesterol, LDL and triglyceride and also has effect in increasing level of HDL plasma with $80 \%$ of concentration as the best concentration.
\end{abstract}

Keywords: lipid profile, shallot (Allium ascalonicum L.)

Penyakit kardiovaskular pada saat ini merupakan masalah kesehatan di negara maju dan merupakan penyebab kematian terbanyak, yaitu sebesar 12 juta pertahun untuk seluruh dunia. Angka ini meningkat untuk negara-negara berkembang, termasuk Indonesia. Pada Survei Kesehatan Rumah Tangga (SKRT) tahun 1972 penyakit kardiovaskuler menjadi penyebab kematian nomor 11 dan pada SKRT berikutnya, tahun 1986, meningkat menjadi nomor 3. Pada SKRT 1992, penyakit ini sudah menjadi penyebab kematian nomor satu untuk usia di atas 40 tahun dan pada SKRT terakhir, tahun 1995 menjadi penyebab kematian nomor satu untuk usia 35-40 tahun. ${ }^{1}$

Penyakit kardiovaskuler yang sering terjadi pada usia produktif adalah penyakit jantung koroner. Penyakit ini sering disebabkan proses aterosklerosis. Etiologi aterosklerosis bersifat multifaktorial dan dislipidemia dianggap sebagai satu faktor risiko

\footnotetext{
1 Penulis untuk korespondensi: Bagian Biokimia FK Universitas Riau.Jl.Diponegoro No.1, Pekanbaru. Email: ismawati75@yahoo.com

2 Bagian Gizi Klinik FK Universitas Riau.Jl.Diponegoro No.1, Pekanbaru. Telp. (0761)-839264, Fax: (0761)-839265

2 Fakultas Kedokteran Unri
}

utama aterosklerosis. Dislipidemia adalah kelainan metabolisme lipid yang ditandai dengan peningkatan maupun penurunan fraksi lipid dalam plasma. Kelainan profil lipid yang utama adalah kenaikan kadar kolesterol total, Low Density Lipoprotein (LDL), trigliserida, serta penurunan kadar High Density Lipoprotein (HDL). ${ }^{2}$ Berbagai studi membuktikan bahwa rasio LDL/HDL merupakan prediktor yang tepat untuk penyakit jantung dan pembuluh darah. Rasio LDL/HDL mencerminkan arus masuk dan keluar kolesterol pada tunika intima pembuluh darah. ${ }^{3}$

Pengobatan tradisional sudah dikenal sejak dulu dan dilaksanakan sebagian masyarakat. ${ }^{4}$ Pemanfaaatan obat tradisional saat ini semakin banyak dilakukan, namun penelitian secara klinis masih jarang atau sedikit dilakukan. Sebagian besar khasiat tanaman obat ini diakui mencegah atau mengurangi suatu jenis penyakit berdasarkan pengalaman yang bersifat turun-temurun. ${ }^{5}$

Tanaman yang dianggap berkhasiat obat diantaranya adalah bawang merah (Allium ascalonicum L.). ${ }^{6}$ Bawang merah sudah lama dikenal masyarakat sebagai obat dan bawang merah sering digunakan untuk menurunkan kadar kolesterol darah 
dan gula darah, antioksidan, antidiuretik, sakit kepala, batuk, pilek, difteri, asma, rematik, hipertensi, mencegah angina pektoris, antikanker, antiaterosklerosis, mengatasi gangguan pencernaan, meningkatkan aktivitas fibrinolitik, antihistamin serta mengobati luka memar. Efek bawang merah ini dihubungkan dengan senyawa fitokimia yang terdapat dalam bawang merah yaitu allisin, alliin, alil propil disulfida, asam fenolat, asam fumarat, asam kafrilat, dihidroalin, floroglusin, fosfor, fitosterol, flavonol, flavonoid, kaempfenol, kuersetin, kuersetin glikosida, pektin, saponin, sterol, sikloaliin, triopropanal sulfoksida, propil disulpida, dan profil-metil disulfida. ${ }^{6}$

Pada orang sehat ekstrak bawang putih yang diberikan bersama makanan berlemak, menurunkan kadar kolesterol serum dalam 3 jam setelah pemberian. Pemberian bawang putih jangka panjang akan menurunkan secara progresif kadar kolesterol serum dan trigliserida baik pada orang normal maupun pada penderita hiperlipidemia. Berdasarkan penelitian, pemberian minyak essensial bawang putih yang juga mengandung allisin setara dengan 1 gram bawang segar/KgBB/hari yang diberikan bersama dengan diet tinggi kolesterol, akan menurunkan kadar kolesterol, trigliserida, VLDL, LDL serta meningkatkan HDL sehingga rasio LDL/HDL menurun. ${ }^{7}$

Bawang merah (Allium ascalonicum L.) juga mengandung allisin. Zat aktif ini yang diduga memiliki efek hipokolesterolemik. Rantai allyl yang tidak jenuh dengan mudah akan tereduksi menjadi rantai propyl yang jenuh, sehingga akan menurunkan kadar NADH yang penting untuk sintesis trigliserida dan kolesterol. Allisin juga mempunyai sifat mengikat $\mathrm{SH}$ group yaitu bagian fungsional dari Co-A yang perlu untuk biosintesis kolesterol. Di samping allisin bawang merah juga mengandung zat aktif lain yang dapat menurunkan kadar lipid darah yaitu flavonoid, allil profil disulpida, kuersetin dan pektin. ${ }^{7}$

Hasil penelitian memperlihatkan bahwa air perasan bawang merah dapat menurnkan kadar kolesterol total mencit putih yang diberi diet tinggi kolesterol. ${ }^{9}$ Tetapi belum diketahui bagaimana pengaruh air perasan bawang merah tersebut terhadap kadar trigliserida dan rasio LDL/HDL mencit putih yang diberi diet tinggi kolesterol. Berdasarkan alasan-alasan di atas maka peneliti ingin melakukan penelitian efek pemberian air perasan bawang merah (Allium ascalonicum L.) terhadap profil lipid plasma mencit.

Tujuan pada penelitian ini adalah mengetahui efek air perasan umbi bawang merah terhadap profil lipid plasma mencit yang diinduksi hiperkolesterolemia.

\section{METODE}

\section{Bahan dan Alat Penelitian}

Penelitian ini menggunakan plasma mencit, EDTA sebagai antikoagulan, air perasan Bawang Merah (Allium ascalonicum L.) sebagai bahan uji, simvastatin sebagai kontrol positif, aquadest sebagai kontrol negatif, kuning telur mentah yang berasal dari jenis ayam ras dan jagung lumat merek B12 sebagai pakan mencit serta reagen trigliserida (Human), reagen HDL (Human), dan reagen kolesterol total (Human).

\section{Prosedur Kerja}

\section{Pemilihan hewan coba}

Penelitian ini dilakukan pada 30 ekor mencit jantan yang berumur 3-4 bulan dengan berat ratarata 30-35 g/ekor. Mencit yang digunakan sebagai hewan coba adalah mencit jantan yang sehat. Mencit dikatakan sehat apabila penampilan fisik tidak tampak kurus, bentuk badan simetris, bergerak gesit, berat badan selama proses adaptasi tidak menurun lebih dari $10 \%$ berat badan semula. ${ }^{9}$

\section{Pemeliharaan}

Mencit diadaptasikan dengan lingkungan baru selama satu minggu. Alas kandang diberi serutan kayu untuk mempercepat serapan kotoran. Kandang diletakkan di ruangan yang berventilasi cukup pada suhu ruangan dengan sirkulasi udara yang baik. Mencit diberi makan dan minum seperti biasa.

\section{Pembagian kelompok perlakuan}

Seluruh hewan percobaan dibagi secara acak dalam 6 kelompok sehingga tiap kelompok terdiri dari 5 ekor mencit. Masing-masing kelompok akan memperoleh perlakuan yang berbeda. 

berikut:

Pembagian kelompok perlakuan adalah sebagai

$\mathrm{P}_{1}$ : kelompok mencit yang diberi diet pakan biasa + air layak minum sebagai kontrol negatif.

$\mathrm{P}_{2}$ : kelompok mencit yang diberi kuning telur $32 \mathrm{~g} / \mathrm{kgBB} / \mathrm{hari}$ di samping pakan biasa + air layak minum

$\mathrm{P}_{3}$ : kelompok mencit yang diberi kuning telur $32 \mathrm{~g} / \mathrm{kgBB} /$ hari di samping pakan biasa + air perasan bawang merah dengan konsentrasi $20 \%$.

$\mathrm{P}_{4}$ : kelompok mencit yang diberi kuning telur $32 \mathrm{~g} / \mathrm{kgBB} /$ hari di samping pakan biasa + air perasan bawang merah dengan konsentrasi $40 \%$.

$\mathrm{P}_{5}$ : kelompok mencit yang diberi kuning telur $32 \mathrm{~g} / \mathrm{kgBB} /$ hari di samping pakan biasa + air perasan bawang merah dengan konsentrasi $80 \%$.

$\mathrm{P}_{6}$ : kelompok mencit yang diberi kuning telur $32 \mathrm{~g} / \mathrm{kgBB} / \mathrm{hari}$ di samping pakan biasa + simvastatin dengan dosis $0,0026 \mathrm{mg} / \mathrm{gBB}$ yang telah dikonversikan dari dosis pada manusia sebagai kontrol positif, dalam bentuk larutan dalam aquades sebanyak $1 \mathrm{ml}$ per oral.

\section{Prosedur pembuatan air perasan bawang merah}

Air perasan bawang merah dibuat sesuai dengan pedoman yang tertera dalam parameter standar umum: ${ }^{10}$

- Bawang merah dikupas kulitnya dan dicuci dengan air bersih.

- Umbi bawang diiris sampai ketebalan menjadi $\pm 2 \mathrm{~mm}$, lalu dikeringkan dengan oven (lemari pengering) pada suhu $40-50^{\circ} \mathrm{C}$ selama $30-36$ jam.

- Setelah kering bawang merah ditimbang 500 gram. Bawang dilumat dengan $100 \mathrm{ml}$ aquadest menggunakan blender.

- Setelah didiamkan 1 jam, lumatan tersebut diperas dengan kain flanel dan sarinya ditampung.

- Air perasan diencerkan dengan aquadest hingga volumenya menjadi $250 \mathrm{ml}$. Dengan demikian, 2 gram bawang merah setara dengan $1 \mathrm{ml}$ air perasan bawang merah atau sama dengan $200 \%$ $\mathrm{b} / \mathrm{v}$.
Untuk mendapatkan pengenceran $20 \%, 40 \%$ dan $80 \%$, air perasan bawang merah diencerkan dengan aquadest steril sesuai dengan rumus $\mathrm{V} 1 \mathrm{xN} 1=\mathrm{V} 2 \mathrm{xN} 2$. Konsentrasi $20 \%$ diperoleh dari penambahan $1 \mathrm{ml}$ air perasan bawang merah dengan $9 \mathrm{ml}$ aquadest steril. Konsentrasi $40 \%$ diperoleh dari penambahan $1 \mathrm{ml}$ air perasan bawang merah dengan $4 \mathrm{ml}$ aquadest steril. Konsentrasi $80 \%$ diperoleh dari penambahan $1 \mathrm{ml}$ air perasan bawang merah dengan $1,5 \mathrm{ml}$ aquadest steril.

\section{Prosedur pemberian perlakuan}

Sebelum pemberian perlakuan, terlebih dahulu hewan coba diberi diet tinggi lemak selama 3 minggu. Diet tinggi lemak yang diberikan pada mencit adalah dengan memberi pakan berupa kuning telur ayam mentah yang berasal dari jenis ayam ras sebanyak $1 \mathrm{ml}$ secara oral dengan menggunakan sonde sehari sekali pada pagi hari selama 3 minggu. Selanjutnya pada prosedur perlakuan diet tinggi lemak diberikan bersama air perasan bawang merah yang diberikan secara oral sebanyak $1 \mathrm{ml}$ selama 2 minggu dengan menggunakan sonde sehari sekali pada pagi hari. Air perasan bawang merah tersebut diberikan setelah pemberian diet tinggi lemak. Interval antara pemberian air perasan bawang merah dengan pemberian pakan tinggi lemak adalah selama 1 jam.

\section{Prosedur pengambilan sampel darah}

Sampel darah diambil dengan cara membedah mencit untuk memperoleh darah sentral yang berasal dari jantung mencit, kemudian darah yang keluar ditampung dalam tabung mikro yang telah berisi antikoagulan untuk selanjutnya dilakukan pengukuran terhadap kadar kolesterol total, trigliserida, HDL, LDL di dalam plasma.

\section{Prosedur pengukuran kadar kolesterol total, HDL, Trigliserida dan LDL}

a. Kolesterol Total

Pengukuran kolesterol total dilakukan sesuai metode CHOD PAP Enzimatic Colorimeter Test. Sampel darah yang telah diambil dimasukkan dalam tabung reaksi, kemudian plasma dipisahkan dari 
darah dengan cara mensetrifuge selama 20 menit dengan kecepatan $1500 \mathrm{rpm}$. Selanjutnya diambil 5 ìL plasma dan ditambahkan $1000 \mathrm{ml}$ reagen, kemudian tabung sampel diinkubasi selama 10 menit pada suhu $20-25^{\circ} \mathrm{C}$. Hasil inkubasi dimasukkan ke dalam spektrofotometer dengan panjang gelombang $500 \mathrm{~nm}$, kemudian hasil pengukuran dibaca dalam satuan $\mathrm{mg} / \mathrm{dl} .{ }^{11}$

\section{b. High Density Lipoprotein (HDL)}

Pengukuran HDL dengan menggunakan metode CHAD-PAP Enzimatic colorimetric Test. Prosedur kerjanya terdiri dari 2 tahap, tahap pertama: siapkan dua buah tabung reaksi, masing-masing tabung masukkan reagen HDL $100 \mu \mathrm{L}$. Setelah itu pada tabung pertama masukkan standart $40 \mu \mathrm{L}$ dan tabung kedua masukkan sampel/plasma $40 \mu \mathrm{L}$. Kemudian campurkan dengan menggoyang-goyangkan tabung reaksi sampai homogen. Selanjutnya inkubasi selama 10 menit pada kecepatan $1500 \mathrm{rpm}$. Tahap ke dua: sediakan tiga buah tabung reaksi, masingmasing tabung masukkan reagen kolesterol $1000 \mu \mathrm{L}$. Tabung pertama digunakan sebagai blanko, tabung yang kedua masukkan HDL supernatan sampel sebanyak $50 \mu \mathrm{L}$ dan tabung ketiga masukkan HDL supernatan sampel sebanyak $50 \mu \mathrm{L}$. Selanjutnya campurkan dengan menggoyang-goyangkan tabung reaksi. Setelah itu inkubasi selama 10 menit pada suhu $20-25^{\circ} \mathrm{C}$ atau suhu ruangan. Kemudian ukur serapan dengan menggunakan spektrofotometer pada panjang gelombang $500 \mathrm{~nm} .^{12}$

\section{c. Trigliserida}

Pengukuran Trigliserida dilakukan sesuai metode GPO-PAP Enzimatic colorimetric Test. Prosedur kerjanya: Siapkan tiga buah tabung reaksi untuk blanko, standart dan untuk sampel. Kemudian masukkan $1000 \mu \mathrm{L}$ reagen trigliserida ke dalam masing-masing tabung reaksi. Setelah itu tambahkan $5 \mu \mathrm{L}$ larutan standart ke dalam tabung reaksi standart dan untuk blanko tidak ditambahkan apa-apa, kemudian tambahkan ke dalam tabung reaksi sampel $5 \mu \mathrm{L}$ plasma. Campurkan dengan menggoyanggoyangkan tabung reaksi. Selanjutnya inkubasi selama 10 menit pada suhu $20-25^{\circ} \mathrm{C}$ atau suhu ruangan. Hasil inkubasi dimasukkan kedalam spektrofotometer dengan panjang gelombang 500 nm kemudian ukur ÄA sampel ÄA standar (STD).

\section{d. Low Density Lipoprotein (LDL)}

Pengukuran LDL berdasarkan rumus Friedewald: $\mathrm{LDL}=$ Kolesterol total $-(\mathrm{HDL}+$ trigliserida / 5 ) ( nilai 1/5 trigliserida itu merupakan nilai VLDL )

\section{HASIL}

Data kadar kolesterol total didapatkan dari hasil penelitian Ismawati ${ }^{8}$, sedangkan data kadar LDL, trigliserida dan HDL yang diperoleh dalam penelitian ini ditunjukkan pada Tabel 1.

Tabel 1. Nilai rata-rata kadar kolesterol total, LDL, trigliserida, dan HDL dan rasio LDL/HDL plasma mencit terhadap berbagai perlakuan

\begin{tabular}{|c|c|c|c|c|c|c|}
\hline \multirow{2}{*}{ Profil lipid } & \multicolumn{6}{|c|}{ Perlakuan } \\
\hline & P1 & $\mathrm{P} 2$ & P3 & P4 & P5 & $\mathrm{P} 6$ \\
\hline $\begin{array}{l}\text { Kolesterol } \\
\text { total } \\
\text { (moddL) }\end{array}$ & $\begin{array}{c}61,7 \pm 5 \\
3\end{array}$ & $\begin{array}{c}149,2 \pm 7,8 \\
*\end{array}$ & $\underset{\wedge}{114,2 \pm 2,1}$ & $74,4 \pm 5,4^{\wedge}$ & $69,4 \pm 6,5^{\wedge}$ & $\begin{array}{c}37,0 \pm 2,8^{*} \\
*\end{array}$ \\
\hline $\begin{array}{c}\text { LDL } \\
(\mathrm{mg} / \mathrm{dL})\end{array}$ & $\begin{array}{c}37,7 \pm 5 \\
2\end{array}$ & $\begin{array}{c}121,3 \pm 7,6 \\
*\end{array}$ & $89,9 \pm 1,4^{\wedge}$ & $51,7 \pm 4,5^{\wedge}$ & $41,7 \pm 6,7^{\wedge}$ & $\begin{array}{c}12,5 \pm 2,4^{*} \\
*\end{array}$ \\
\hline $\begin{array}{c}\text { Trig lise rida } \\
\text { (mg/dL) }\end{array}$ & $\begin{array}{l}30,6 \pm 3, \\
3\end{array}$ & $\begin{array}{c}84,4 \pm 3,92 \\
*\end{array}$ & $\underset{\wedge}{72,9 \pm 3,81}$ & $\underset{\wedge}{53,5 \pm 3,13}$ & $37,1 \pm 3,61$ & $\begin{array}{c}22,9 \pm 2,8^{*} \\
*\end{array}$ \\
\hline$\underset{\text { HDL }}{\mathrm{H} \text { (mg/dL }}$ & $\begin{array}{c}17,8 \pm 1 \\
1\end{array}$ & $\begin{array}{c}10,9 \pm 1,08 \\
*\end{array}$ & $13,6 \pm 0,9^{\wedge}$ & $16,1 \pm 0,9^{\wedge}$ & $17,4 \pm 0,8^{\wedge}$ & $\begin{array}{c}20,0 \pm 1,1 * \\
*\end{array}$ \\
\hline $\begin{array}{c}\text { Rasio } \\
\text { LDL/HDL }\end{array}$ & 2,1 & 11,1 & 6,6 & 2,4 & 2,4 & 0,6 \\
\hline
\end{tabular}


Tabel 1 menunjukkan bahwa nilai rata-rata kadar kolesterol total, LDL dan trigliserida plasma mencit, dari yang terbesar sampai yang terkecil berturut-turut adalah kelompok kuning telur, kelompok air perasan bawang merah $20 \%$, kelompok air perasan bawang merah $40 \%$, kelompok air perasan bawang merah $80 \%$, kelompok aquadest dan kelompok simvastatin. Tabel 1 juga menunjukkan bahwa nilai rata-rata kadar HDL plasma mencit dari yang terbesar sampai yang terkecil berturut-turut adalah kelompok simvastatin, kelompok aquadest, kelompok air perasan $80 \%$, kelompok air perasan $40 \%$, air perasan $20 \%$ dan kelompok kuning telur.

Berdasarkan Tabel 1 dapat dilihat bahwa profil lipid kelompok kuning telur memiliki perbedaan yang bermakna secara statistik dengan kelompok kontrol. Demikian juga profil lipid kelompok air perasan bawang merah 20\%, $40 \%$ dan $80 \%$ memiliki perbedaan yang bermakna secara statistik dengan kelompok kuning telur. Sedangkan kelompok simvastatin sebagai kontrol positif memiliki perbedaan yang bermakna secara statistik dengan kelompok air perasan bawang merah 20\%, 40\% dan $80 \%$.

Analisis post Hoc menunjukkan bahwa profil lipid air perasan bawang merah $20 \%$ memiliki perbedaan yang bermakna secara statistik dengan air perasan bawang merah $40 \%$ dan $80 \%$. Demikian juga profil lipid air perasan bawang merah $40 \%$ juga berbeda secara bermakna dengan air perasan bawang merah $80 \%$.

Rasio LDL/HDL pada kelompok air perasan bawang merah $80 \%$ dan $40 \%$ sama. Rasio LDL/ HDL pada kelompok tersebut tidak berbeda bermakna dengan kelompok aquades, tetapi lebih rendah daripada kelompok kuning telur. Meskipun demikian kelompok yang diberi simvastatin memiliki rasio LDL/HDL yang lebih rendah terhadap semua kelompok.

\section{PEMBAHASAN}

\section{Pengaruh Pemberian Diet Tinggi Lemak}

Berdasarkan hasil penelitian yang diperoleh bahwa terdapat perbedaan kadar kolesterol total, HDL, trigliserida, dan LDL plasma mencit yang diberi perlakuan diet tinggi lemak dengan kelompok perlakuan yang tidak diberi diet tinggi lemak (aquadest). Hal ini dapat dilihat pada Tabel 1 yang menunjukkan bahwa terdapat perbedaan nilai ratarata kolesterol total, HDL, trigliserida, dan LDL plasma antara kelompok aquadest berturut-turut yaitu sebesar $61,66 \mathrm{mg} / \mathrm{dl}, 17,81 \mathrm{mg} / \mathrm{dl}, 30,59 \mathrm{mg} /$ dl, dan37,73 dan kelompok kuning telur yaitu sebesar 149,16 mg/dl, 10,96 mg/dl, 84,43 mg/dl, dan $121,32 \mathrm{mg} / \mathrm{dl}$.

Berdasarkan uji statistik yang dilakukan terhadap kedua kelompok tersebut didapatkan juga perbedaan yang bermakna antara kelompok perlakuan, sehingga dapat disimpulkan bahwa pemberian kuning telur kepada mencit perlakuan terbukti dapat menimbulkan kenaikan kadar kolesterol total, trigliserida dan LDL plasma serta dapat menurunkan kadar HDL plasma mencit. Hasil ini sesuai teori yang menyatakan bahwa kuning telur merupakan salah satu sumber kolesterol yang tinggi, satu kuning telur mengandung 220-250 mg kolesterol. Kuning telur juga mengandung lemak jenuh yang sangat signifikan dapat meningkatkan kolesterol darah, hal ini terjadi karena asam lemak jenuh menghasilkan acetil-coA yang dapat disintesis menjadi kolesterol. ${ }^{13,14}$

Diet tinggi kolesterol dan lemak jenuh menyebabkan peningkatan kolesterol intrasel dan kolesterol tersebut akan disimpan sebagai ester kolesterol. Disamping itu, diet ini juga menyebabkan terjadinya penurunan transkripsi gen reseptor LDL yang mengakibatkan sintesis reseptor LDL menurun. Hal ini menyebabkan kadar LDL di dalam sirkulasi akan meningkat. ${ }^{15}$ Kadar trigliserida dalam darah tergantung konsumsi makanan, jumlah dan jenis lemak yang terdapat dalam makanan. Diet yang mengandung lemak jenuh akan meningkatkan kadar trigliserida dalam darah. ${ }^{16}$

\section{Pengaruh Pemberian Air Perasan Bawang Merah}

Berdasarkan hasil penelitian yang diperoleh, air perasan bawang merah dapat menurunkan kadar kolesterol total, trigliserida, dan LDL serta dapat meningkatkan kadar HDL plasma mencit yang telah diinduksi menjadi dislipidemia. Berdasarkan Tabel 1, dapat disimpulkan bahawa air perasan bawang merah 20\%, air perasan bawang merah $40 \%$ dan air perasan bawang merah $80 \%$ memberikan efek 
penurun kadar kolesterol total, trigliserida, dan LDL. Tetapi efek hipolipidemik air perasan bawang merah masih lebih rendah dibandingkan simvastatin. Ratarata kadar HDL plasma mencit pada kelompok air perasan bawang merah $20 \%$, air perasan bawang merah $40 \%$ dan air perasan bawang merah $80 \%$ memberikan efek peningkatan kadar HDL plasma mencit yang lebih kecil dibandingkan dengan simvastatin.

Hasil analisis statistik dengan uji anova menunjukkan bahwa terdapat perbedaan yang bermakna $(p<0,05)$ antara besarnya kadar kolesterol total, HDL, trigliserida dan LDL plasma mencit yang telah diberi air perasan bawang merah. Kemudian dilanjutkan dengan uji post hoc didapatkan hasil bahwa kadar kolesterol total pada kelompok air perasan bawang merah $80 \%$ memiliki perbedaan yang bermakna secara statistik dibanding dengan air perasan $20 \%$, air perasan bawang merah $40 \%$, kuning telur, simvastatin dan aquadest. Hal ini berarti efek penurun kolesterol dari air perasan bawang merah $80 \%$ secara statistik lebih baik dibanding air perasan bawang merah $20 \%$ dan air perasan bawang merah $40 \%$, tetapi lebih rendah jika dibandingkan dengan simvastatin. Hal ini berbeda dengan kadar HDL, trigliserida, dan LDL pada kelompok air perasan bawang merah $80 \%$ tidak memiliki perbedaan yang bermakna dengan kelompok aquadest, ini berarti kadar HDL, trigliserida, dan LDL relatif sama dengan kelompok yang tidak diberi diet tinggi lemak (aquadest). Air perasan bawang merah $80 \%$ merupakan konsentrasi yang terbaik dalam menurunkan kolesterol total, trigliserida, dan LDL plasma mencit serta merupakan konsentrasi terbaik dalam meningkatkan kadar HDL plasma mencit dibandingkan dengan konsentrasi air perasan bawang merah lainnya.

Air perasan bawang merah dengan konsentrasi $40 \%$ memiliki perbedaan yang bermakna secara statistik dibanding dengan air perasan bawang merah $20 \%$, air perasan bawang merah $80 \%$, kuning telur, simvastatin dan aquadest. Hal ini berati efek penurun kolesterol total, trigliserida dan LDL serta peningkatan kadar HDL air perasan bawang merah $40 \%$ secara statistik lebih baik dibanding air perasan bawang merah $20 \%$ tetapi lebih rendah jika dibandingkan dengan air perasan bawang merah $80 \%$ dan simvastatin.
Begitu juga dengan air perasan bawang merah dengan konsentrasi $20 \%$ memiliki perbedaan yang bermakna secara statistik dengan air perasan bawang merah $40 \%$, air perasan bawang merah $80 \%$, kuning telur, simvastatin dan aquadest. Hal ini berarti air perasan bawang merah dengan konsentrasi $20 \%$ memiliki efek penurunan kolesterol total, trigliserida dan LDL serta peningkatan kadar HDL plasma tetapi lebih rendah jika dibandingkan dengan air perasan bawang merah $40 \%$, air perasan bawang merah $80 \%$ dan simvastatin.

Adanya penurunan kadar kolesterol total, LDL, dan trigliserida plasma mencit menunjukkan bahwa air perasan bawang merah mengandung senyawa aktif yang bersifat hipolipidemik. Salah satu bahan aktif ini yaitu allisin, adapun mekanisme kerja allisin adalah melalui penghambatan sintesis kolesterol endogen. Rantai allyl yang tidak jenuh dengan mudah akan tereduksi menjadi rantai propyl yang jenuh, sehingga akan menurunkan kadar NADH yang penting untuk sintesa trigliserida dan kolesterol. Allisin juga mempunyai sifat mengikat SH group yaitu bagian fungsional dari Co-A yang perlu untuk biosintesis kolesterol. ${ }^{7}$ Adanya peningkatan kadar HDL juga disebabkan oleh senyawa aktif yang terkandung dalam bawang merah yaitu allisin dan allin. Menurut Widjaja Kusuma, mengkonsumsi satu siung bawang merah segar dapat meningkatkan kadar HDL sebesar 30\%. ${ }^{6}$

Adanya perbedaan profil lipid plasma mencit pada berbagai konsentrasi menunjukkan bahwa perbedaan konsentrasi mempengaruhi efektivitas suatu obat. ${ }^{17}$ Dalam hal ini, air perasan bawang merah $80 \%$ memberikan efek penurunan kolesterol total, LDL, dan trigliserida paling besar terhadap plasma mencit dibandingkan konsentrasi lainnya. Selain itu air perasan bawang merah $80 \%$ juga memberikan efek peningkatan kadar HDL paling besar diantara konsentrasi lainnya. Hal ini dapat terjadi karena bioaktivitas suatu fitofarmaka sangat dipengaruhi oleh interaksi senyawa yang ada di dalamnya. Konsentrasi air perasan bawang merah yang memungkinkan terjadinya interaksi optimal akan memberikan aktivitas yang optimal pula. ${ }^{18}$

Rasio LDL/HDL pada kelompok yang diberi air perasan bawang merah $80 \%$ adalah 2,4 . Nilai ini tidak berbeda bermakna dengan rasio LDL/HDL kelompok yang diberi aquades. Hal ini menunjukkan 
bahwa air perasan bawang merah efektif dalam memperbaiki profil lipid. Rasio LDL/HDL ini merupakan prediktor yang baik untuk penyakit jantung pembuluh darah. ${ }^{3}$

\section{Pengaruh Pemberian Simvastatin}

Berdasarkan Tabel 1 didapatkan rata-rata kadar kolesterol total, trigliserida dan LDL plasma dari kelompok simvastatin sebagai kontrol positif secara berturut-turut sebesar 37,04 mg/dl, 22,93 mg/dl, dan $12,45 \mathrm{mg} / \mathrm{dl}$. Hal ini berarti kadar kolesterol total, trigliserida dan LDL plasma mencit pada kelompok simvastatin mengalami penurunan dan memiliki perbedaan yang bermakna berdasarkan analisis statistik dengan kelompok perlakuan air perasan bawang merah $20 \%$, air perasan bawang merah $40 \%$, air perasan bawang merah $80 \%$, kuning telur dan aquadest. Hal ini berati efek penurun kolesterol total, trigliserida dan LDL dari simvastatin secara statistik lebih baik dibanding dengan kelompok perlakuan yang lainnya tetapi lebih rendah jika dibandingkan dengan kelompok aquadest sebagai kontrol negatif. Rata-rata kadar HDL plasma mencit dari kelompok simvastatin sebesar 20,00 mg/dl. Hal ini berarti kadar HDL plasma mencit pada kelompok simvastatin mengalami peningkatan dan memiliki perbedaan yang bermakna berdasarkan analisis statistik dengan kelompok perlakuan air perasan bawang merah $20 \%$, air perasan bawang merah $40 \%$, air perasan bawang merah $80 \%$, kuning telur dan aquadest. Keadaan demikian mungkin disebabkan karena bioavailabilitas dari simvastatin yang lebih panjang dari perkiraan dosis pada manusia terjadi di plasma mencit akibat simvastatin dapat mencapai sirkulasi sistemik mencit dalam bentuk utuh atau aktif. ${ }^{17}$

\section{KESIMPULAN}

Penelitian tentang efek air perasan umbi bawang merah terhadap profil lipid plasma mencit dapat disimpulkan bahwa air perasan bawang merah mempunyai pengaruh terhadap penurunan kadar kolesterol total, LDL dan trigliserida plasma mencit serta air perasan bawang merah dapat meningkatkan kadar HDL plasma mencit.

\section{UCAPAN TERIMA KASIH}

Penulis mengucapkan terima kasih yang sebesar-besarnya kepada Fakultas Kedokteran Universitas Riau atas segala fasilitas dan kemudahan yang diberikan kepada penulis selama melaksanakan penelitian ini.

\section{DAFTAR PUSTAKA}

1. Lipoeto NI. Konsumsi lemak dan Resiko Penyakit Kardiovaskuler. Medika 2000;11: 73032.

2. Subekti I. Pengelolahan dislipidemia pada tingkat pelayanan primer. Maj Kedokt Indon 2005; 55: 285-290.

3. Fernandez ML, Webb D. The LDL to HDL cholesterol ratio as a valuable tool to evaluate coronary heart disease risk. Journal of the American College of Nutrition 2008; 1: 1-5.

4. Muhlisah F, Hening S. Sayur dan Bumbu Dapur Berkhasiat Obat. Jakarta: Penebar Swadaya, 2000.

5. Mulyani S, Gunawan D. Ramuan Tradisional Untuk Penderita Asma. Jakarta: Penebar Swadaya, 2004.

6. Jaelani. Khasiat Bawang Merah. Yokyakarta: Kanisius, 2007.

7. Sunarto P, Pikir BS. Pengaruh Garlic Terhadap Penyakit Jantung Koroner. 2000; http:// www.Kalbe.co.id. [diakses 20 Juni 2009].

8. Ismawati, Hamidy M.Y, Clara D.S. Efek Hipolipidemik air perasan umbi bawamg merah (Allium ascalonicum L.) pada mencit putih (Mus musculus). Jurnal Ilmu Kedokteran 2009; 2: 102106.

9. Suhardjono D. Teknik Bekerja dengan Hewan Laboratorium. Yogyakarta: Universitas Gajah Mada; 1991.

10.Departemen Kesehatan RI. Parameter Standar Umum Ekstrak Tumbuhan Obat. Jakarta: Direktorat Jenderal Pengawasan Obat dan Makanan, 1985.4-15.

11. Rahayu T. Kadar Kolesterol Darah Tikus Putih (Rattus norvegicus L) Setelah Pemberian Cairan 
Kombucha Per-Oral. Surakarta: Jurnal Penelitian Sains \& Teknologi 2005; 2: 85-100.

12.Tim Biokimia FK UR. Penuntun Praktikum Biokimia.Pekanbaru: Bagian Biokimia FK UR, 2009.

13.Anggreini CD, Subando J, Kustiwinarni. Pengaruh Pemberian Angkak terhadap Kadar Kolesterol Total Darah Tikus Putih (Rattus norvegicus). Cermin Dunia kedokteran 2009;168: 94-5.

14.Sediaoetama AD. Ilmu Gizi. Jakarta: Dian Rakyat; 2000.

15.Kotiah U. Pengaruh Pemberian Ekstrak Lidah
Buaya terhadap Kadar Kolesterol HDL dan LDL Serum Tikus Putih Hiperkolesterolemi. 2007; http://www.digilib.unnes.ac.id [diakses 09 Oktober 2009]

16.Suichan M, Rukmi MGI. Effect of Tempe Gembus on Cholesterol Profil in Hyperlipidemic rats. Med J indon 2007; 16: 205-11.

17.Ganiswara SG. Farmakologi dan Terapi. Edisi 4. Jakarta: Fakultas Kedokteran Universitas Indonesia; 1999.

18. Harborne JB. Metode Fitokomia: Penuntun Cara Modern Menganalisa Tumbuhan. Bandung: Institut Teknologi Bandung; 1987. 